\title{
QUALITY AND SENSORIAL CHARACTERISTICS OF OSMOTICALLY DEHYDRATED MANGO WITH SYRUPS OF INVERTED SUGARAND SUCROSE
}

\author{
Sabrina Bernardi ${ }^{1}$; Renata B. Bodini ${ }^{1}$; Bruna Marcatti ${ }^{1}$; Rodrigo Rodrigues Petrus ${ }^{2}$; Carmen \\ Sílvia Favaro-Trindade ${ }^{2 *}$ \\ ${ }^{1}$ USP/FZEA - Graduação em Engenharia de Alimentos \\ ${ }^{2}$ USP/FZEA - Depto. de Engenharia de Alimentos - C.P. 23 - 13635-900 - Pirassununga, SP - Brasil. \\ *Corresponding author <carmenft@usp.br>
}

\begin{abstract}
Osmotic dehydration is becoming more popular as a complementary treatment in the processing of dehydrated foods, since it presents some advantages such as minimising heat damage to the colour and flavour, inhibiting enzymatic browning and thus dispensing the addition of sulphite and, mainly, reducing energy costs. The objective of the present study was to evaluate the effect of using inverted sugar and sucrose syrups as osmotic agents in the dehydration of mango. The conditions used in the dehydration process were: syrup/fruit ratio of $3: 1(\mathrm{v} / \mathrm{w})$; temperature of $45^{\circ} \mathrm{C}$ and constant stirring. The in natura and osmo-dehydrated fruits were evaluated in relation to $\mathrm{pH}$, moisture content, water activity $\left(\mathrm{a}_{\mathrm{w}}\right)$ and soluble solids ( $\left.{ }^{\circ} \mathrm{Brix}\right)$. Solids incorporation and loss in mass after the dehydration process were also determined. The sensory acceptance of the in natura and osmo-dehydrated fruits was determined for the attributes of aroma, flavour, texture and overall acceptance using a hedonic scale. Osmotic dehydration resulted in a reduction in moisture content and water activity, an increase in Brix and maintenance of the $\mathrm{pH}$. The treatment with inverted sugar syrup resulted in more significant alterations in moisture content, $\mathrm{a}_{\mathrm{w}}$, Brix, solids incorporation and loss in mass than the treatment with sucrose syrup. Mangos osmo-dehydrated with inverted sugar (55.3\% inversion rate) syrup obtained acceptance similar to in natura mangos, this treatment being considered the most adequate for dehydration purposes.
\end{abstract}

Key words: Mangifera indica, sensory acceptance, loss in mass, solids incorporation

\section{QUALIDADE E CARACTERÍSTICAS SENSORIAIS DE MANGA OSMOTICAMENTE DESIDRATADACOM XAROPES DEAÇÚCAR INVERTIDO EASACAROSE}

\begin{abstract}
RESUMO: A desidratação osmótica tem se tornado uma tecnologia cada vez mais usual no processamento de alimentos desidratados, por apresentar vantagens como a redução nas perdas de cor e sabor durante o tratamento térmico, inibição do escurecimento enzimático, prescindindo da adição de agentes sulfitantes, e principalmente economia no consumo de energia. Este trabalho avaliou o efeito da utilização de xaropes de açúcar invertido e sacarose como agentes osmóticos na desidratação de manga. As condições utilizadas no processo de desidratação foram: relação xarope/fruto de 3:1(v/ p); temperatura de $45^{\circ} \mathrm{C}$ e agitação constante. Os frutos in natura e osmo-desidratados foram avaliados quanto ao $\mathrm{pH}$, umidade, atividade de água $\left(\mathrm{a}_{\mathrm{a}}\right)$ e sólidos solúveis ( $\left.{ }^{\circ} \mathrm{Brix}\right)$. Determinou-se a incorporação de sólidos e a perda de massa após o processo de desidratação. A aceitação sensorial dos frutos in natura e osmo-desidratados foi avaliada através de um teste com escala hedônica, para os atributos aroma, sabor, textura e aceitação global. A desidratação osmótica resultou na redução da umidade e da $\mathrm{a}$, no aumento do Brix e na manutenção do $\mathrm{pH}$ da manga. Os tratamentos com xarope de açúcar invertido ocasionaram mais alterações na umidade, na $\mathrm{a}_{\mathfrak{a}}$, no Brix, na incorporação de sólidos e na perda de massa comparado ao tratamento com xarope de sacarose. As mangas osmo-desidratadas com o xarope de açúcar invertido (55,3\% de taxa de inversão) obtiveram uma aceitação semelhante às mangas in natura, tendo sido considerado o tratamento mais adequado para esse fim.

Palavras-chave: Mangifera indica, aceitação sensorial, perda de massa, incorporação de sólidos.
\end{abstract}

\section{INTRODUCTION}

The mango (Mangifera indica L.) is one of the most cultivated tropical fruits in the World, with India, China and Mexico being the main producers. The fruit is an excellent source of fibre and vitamins A, C 
and the B complex, and has become more and more appreciated by consumers (Tedjo et al., 2002).

Osmotic dehydration is a complementary treatment in the processing of dehydrated foods, since it presents some advantages such as minimising heat damage to the colour and flavour, inhibiting enzymatic browning and reducing energy costs (Alakali et al., 2006; Torres et al., 2006, 2007). In addition it has proved to be a good method to obtain minimally processed fruits, due to the great sensory similarity between the dehydrated and in natura products (Lerici et al., 1985; Sousa et al., 2003).

The technique aims to dehydrate food products by immersing them in a hypertonic solution. Water is removed due to the difference of osmotic potencial between the food and the osmotic solution, reducing the water activity of the food and consequently the water availability for chemical and biological deterioration. During the process two simultaneous flows through the cell walls are created in counter current: one of water leaving the fruit to the solution the most important from the dehydration point of view - and other of osmotic solute (usually a salt or sugar) from the solution into the fruit (Ordóñez, 2005).

Vial et al. (1991) evaluated the use of inverted sugar as osmotic agent in the osmotic dehydration of kiwi. However, due to its lower cost, sucrose is the most used sugar in the majority of studies using this technique.

The objective of the present study was to investigate the effect of using commercial inverted sugar and sucrose syrups as osmotic agents in the dehydration of mango, and to evaluate the physical-chemical and sensorial characteristics of the osmotically dehydrated products as compared to the in natura fruits.

\section{MATERIALAND METHODS}

Mangos (Magnifera indica L., Tommy Atkins variety) were acquired from the local market, being a variety that corresponds to $95 \%$ of the volume of mango cultivated in Brazil (Anuário Brasileiro de Fruticultura, 2006).

Three commercial syrups were used as hypertonic solutions: sucrose syrup of $66^{\circ} \mathrm{Brix}$, denominated as treatment 1 (T1); inverted sugar syrup of $66^{\circ}$ Brix with a $55.3 \%$ inversion rate, treatment 2 (T2) and inverted sugar syrup of $66^{\circ}$ Brix with a $92.3 \%$ rate of inversion, treatment 3 (T3). In natura mangos were used as control.

Pre-processing - Fruits were duly selected according to the appearance of the skin and the texture, washed under running water, manually peeled and sliced into $10 \mathrm{~cm}$ long sticks with a cross-sectional area of approximately $0.5 \mathrm{~cm}^{2}$.
Osmotic dehydration - Mango sticks were immersed into the syrups in the proportion of 1:3 (one part of mango to three of syrup) in $2 \mathrm{~L}$ screw-topped glass recipients. These were submitted to constant shaking for $4 \mathrm{~h}$ at $45^{\circ} \mathrm{C}$ in a water bath with orbital shaking and rotational speed of $100 \mathrm{rpm}$. At the end of the process the syrups were drained off and the mango sticks washed under running water for $2 \mathrm{~min}$ to eliminate the excess of syrup on the surface, and then dried with paper.

Physicochemical characterization of the fruits The physicochemical analyses were carried out on the in natura (control) and osmo-dehydrated fruits in triplicate. The water activity was determined by direct reading. The $\mathrm{pH}$ was determined using a $\mathrm{pH}$-meter. Soluble solids as Brix were determined by direct reading of a portable refractometer, and the water content was determined using the method recommended by the Instituto Adolfo Lutz (1985).

Solids incorporation - Solids incorporation into the fruit was calculated according to the following formula, as applied by Azeredo \& Jardine (2000):

$I S(\%)=100 \cdot\left[\left(S T_{f} \times m_{f}\right)-\left(S T_{i} \times m_{i}\right)\right] / m_{i}$

where $I S(\%)$ is the incorporation of solids based on the initial sample mass; $S T_{f}$ is the final total solids content of the sample (\%); $S T_{i}$ is the initial total solids content of the sample (\%); $m_{f}$ is the final sample mass (g), and $m_{i}$ is the initial sample mass $(\mathrm{g})$.

Loss in mass during the process - The loss in mass was determined using a semi-analytical balance, as described by Angelini (2002) and calculated according to the following equation:

$P P(\%)=100 \cdot\left[1-\left(m_{f} / m_{i}\right)\right]$

where $P P(\%)$ is the loss in mass of the sample; $m_{f}$ is the final sample mass $(\mathrm{g})$, and $m_{i}$ is the initial sample mass $(\mathrm{g})$.

Sensory evaluation - The control (mango in natura) and osmo-dehydrated samples were analysed by 45 panellists, all consumers of this fruit. A structured 9point hedonic scale was used to evaluate acceptance of the product with respect to the attributes of aroma, flavour, texture and overall acceptance (Meilgaard et al., 1999). A test for buying intention was carried out simultaneously. The samples were served on disposable plates at a temperature of approximately $12^{\circ} \mathrm{C}$.

Statistical analyses of the results - Obtained data were statistically analysed using the analysis of variance (ANOVA), and the Tukey test applied to compare the means using the 8.02 version of the SAS Software (2001). 


\section{RESULTS AND DISCUSSION}

\section{Physicochemical evaluation}

Fruits treated with inverted sugar reached lower $\mathrm{a}_{\mathrm{w}}$ values $(p<0.05)$ than those treated with sucrose syrup, mainly due to the lower water content and higher solids incorporation attained after the inverted syrup treatments, comparing with the sucrose syrup treatment (Table 1). However, treatments T2 and T3 were not different $(p>0.05)$ even though treatment T3 used a syrup containing a higher concentration of fructose and glucose than T2 due to its higher conversion rate.

Syrups of the same concentration and osmotic agents showed that fruits treated with fructose syrup reached lower $a_{w}$ values than those treated with sucrose syrups, results that are similar to those obtained in the present study (Bolin et al, 1983). All treatments resulted in reduction in water activity as compared to the fruit in natura, although the values obtained were still sufficiently high for the development of a wide spectrum of microorganisms (Table 1).

There was no difference $(p>0.05)$ between the $\mathrm{pH}$ values obtained for the fruits in natura and those obtained for the osmo-dehydrated fruits, suggesting that the osmotic dehydration did not cause loss of organic acids. This result differed from that obtained by Angelini (2002), where osmo-dehydrated kiwi fruit presented higher $\mathrm{pH}$ values than the fruit in natura. The $\mathrm{pH}$ values found in the present study allow for the growth of some pathogenic microorganisms and of many deteriorative ones, especially yeasts and moulds.

When used in combination with other preservation methods, such as the use of chemical preservatives, osmotic dehydration can provide products that, despite their high water activity, remain stable at room temperature and show similar sensorial characteristics when compared with in natura products. Refrigeration could also be an alternative to extend the shelf life of osmo-dehydrated fruits (Angelini, 2002).
The use of sucrose syrup in the osmotic dehydration process caused a greater loss in mass $(p<$ 0.05 ) than the treatments with inverted sugar, which showed no difference between themselves (Table 2). Fruits treated with inverted sugar, however, incorporated a greater quantity of solids because the low molecular weight carbohydrates penetrate easily into the cellular structure of the fruit tissue. On the other hand, higher molecular weight molecules cause greater dehydration (Sousa et al., 2003). There was no difference $(p>0.05)$ between treatments T2 and T3, despite the fact that the syrup used in treatment T3 had suffered a greater rate of inversion (Table 2).

Sensorial evaluation - The parameters employed in the process of osmotic dehydration for treatments $\mathrm{T} 1$ and $\mathrm{T} 2 \mathrm{did}$ not cause any differences in the aroma $(p>0.05)$ (Table 3). Treatment T3 was different from the other treatments, with a lower acceptance and with a mean within the range: disliked slightly to indifferent. The lower acceptance of this treatment could have been due to the presence of aromatic compounds in the syrup caused by caramelization due to the drastic inversion rate suffered by this syrup (92.3\%).

For flavour, the fresh fruit had the highest mean value, although this did not differ from the values obtained for treatments T1 and T2. Treatment T3 had a smaller mean, differing only from that obtained by the mango in natura. The lower acceptance of the fruits from treatment T3 can be attributed to losses in sensory quality of the syrup during the inversion process, since its inversion rate was much higher than that of $\mathrm{T} 2$.

The mango in natura stood out from all other treatments, with a higher mean for texture. The other treatments did not differ, and their acceptance was low. Probably the process conditions $\left(45^{\circ} \mathrm{C}\right.$ and $\left.4 \mathrm{~h}\right)$ were drastic, resulting in lower sensory quality products.

The Tommy Atkins variety contains an elevated fibre content which became, from a sensory point of view, more evident after osmotic dehydration. This fact was considered a sensory negative aspect by various panellists. With respect to the overall acceptance, only

Table 1 - Physicochemical characterization of in natura mangos and those osmo-dehydrated in sucrose and invert sugar syrups (means \pm standard deviation).

\begin{tabular}{lcccc}
\hline Treatment & Moisture content & Water activity & $\mathrm{pH}$ & Soluble solids \\
\hline & $\%$ & & & ${ }^{\circ}$ Brix \\
Control & $86.8 \pm 3.1^{\mathrm{a}}$ & $0.98 \pm 0.00^{\mathrm{a}}$ & $4.9 \pm 0.3^{\mathrm{a}}$ & $13 \pm 1.0^{\mathrm{a}}$ \\
T1 & $68.3 \pm 2.3^{\mathrm{b}}$ & $0.96 \pm 0.00^{\mathrm{b}}$ & $4.8 \pm 0.1^{\mathrm{a}}$ & $30 \pm 1.7^{\mathrm{b}}$ \\
T2 & $63.8 \pm 2.0^{\mathrm{c}}$ & $0.94 \pm 0.01^{\mathrm{c}}$ & $4.9 \pm 0.3^{\mathrm{a}}$ & $35 \pm 1.3^{\mathrm{c}}$ \\
T3 & $65.7 \pm 2.9^{\mathrm{b}, \mathrm{c}}$ & $0.93 \pm 0.02^{\mathrm{c}}$ & $4.7 \pm 0.3^{\mathrm{a}}$ & $34 \pm 1.0^{\mathrm{c}}$ \\
\hline
\end{tabular}

a,b,c, Means with the same exponent, in the same column, are not different $(p>0.05)$. Control: mango in natura. T1: sucrose syrup, T2: invert sugar syrup (55.3\% inversion rate), T3: invert sugar syrup ( $92.3 \%$ inversion rate). 
Table 2 - Loss in mass and solids incorporation for the different treatments (means \pm standard deviation).

\begin{tabular}{lcc}
\hline Treatment & Loss in mass & Solids incorporation \\
\hline & $53.1 \pm 2.3^{\mathrm{a}}$ & $21.53 \pm 0.3^{\mathrm{a}}$ \\
T1 & $46.3 \pm 1.6^{\mathrm{b}}$ & $23.78 \pm 0.3^{\mathrm{b}}$ \\
T2 & $47.3 \pm 1.1^{\mathrm{b}}$ & $23.56 \pm 0.9^{\mathrm{b}}$ \\
\hline
\end{tabular}

${ }^{\mathrm{a}, \mathrm{b}}$ Means with the same exponent, in the same column, are not different $(p>0.05)$. Control: mango in natura. T1: sucrose syrup, T2: invert sugar syrup (55.3\% inversion rate), T3: invert sugar syrup ( $92.3 \%$ inversion rate).

Table 3 - Means obtained in the sensory acceptance test for in natura and osmo-dehydrated mangos.

\begin{tabular}{lcccc}
\hline Treatment & Aroma & Flavour & Texture & $\begin{array}{c}\text { Overall } \\
\text { acceptance }\end{array}$ \\
\hline Control & $6.87^{\mathrm{a}}$ & $6.09^{\mathrm{a}}$ & $6.91^{\mathrm{a}}$ & $6.47^{\mathrm{a}}$ \\
$\mathrm{T} 1$ & $6.13^{\mathrm{a}}$ & $5.49^{\mathrm{ab}}$ & $4.76^{\mathrm{b}}$ & $5.38^{\mathrm{b}}$ \\
$\mathrm{T} 2$ & $6.16^{\mathrm{a}}$ & $5.91^{\mathrm{ab}}$ & $5.16^{\mathrm{b}}$ & $5.69^{\mathrm{ab}}$ \\
$\mathrm{T} 3$ & $4.56^{\mathrm{b}}$ & $4.91^{\mathrm{b}}$ & $5.20^{\mathrm{b}}$ & $5.27^{\mathrm{b}}$ \\
\hline
\end{tabular}

a,b Means with the same exponent, in the same column, are not different $(p>0.05)$. Control: mango in natura. T1: sucrose syrup, T2: invert sugar syrup (55.3\% inversion rate), T3: invert sugar syrup (92.3\% inversion rate). Scores based on a 9-point scale, where 1 corresponds to "disliked extremely" and 9 to "liked extremely".

treatment T2 did not differ from the control, which had the highest mean. It is possible for an osmo-dehydrated product to present acceptance similar to that of the fruit in natura. No difference $(p>0.05)$ was detected between treatments T1, T2 and T3.

Comments made by the panellists suggested that the osmotic dehydration process led to products with the appearance of overripe fruit or of fruit in an advanced stage of ripeness. This problem could be overcome by the use of a less fibrous variety or fruit in a less advanced stage of maturity, as well as using shorter processing times and lower temperatures. On the other hand, the process employed eliminated the need for blanching or the addition of sulphites, since the osmo-dehydrated fruits did not suffer enzymatic browning.

\section{CONCLUSIONS}

Osmotic dehydration resulted in a reduction in the water content and $\mathrm{a}_{\mathrm{w}}$, reduction in energy consumption in subsequent operations such as conventional drying. The treatments with inverted sugar syrup caused more changes in water content, $\mathrm{a}_{\mathrm{w}}$, Brix, solids incorporation and loss of mass than the treatment with sucrose syrup. The sensory evaluation for tex- ture showed that the variety Tommy Atkins was not the most indicated variety for the osmotic dehydration process. The conditions employed in the osmotic dehydration process dispensed the need to add sulphite or carry out a blanching process; however they were harmful to the texture of the products. The mangos osmo-dehydrated with inverted sugar syrup (inversion rate of $55.3 \%$ ) had acceptance scores similar to those of mangos in natura, suggesting that this was the most adequate treatment for the osmotic dehydration of mango.

\section{REFERENCES}

ALAKALI, J.S.; ARIAHU, C.C.; NKPA, N.N. Kinetics of osmotic dehydration of mango. Journal of Food Processing and Preservation, v.30, p.597-607, 2006.

ANGELINI, R. Desidratação osmótica de kiwi (Actinidia deliciosa L): estudo da reutilização da solução osmótica. Campinas: Universidade Estadual de Campinas, 2002. 72p. (Mestrado).

ANUÁRIO BRASILEIRO DE FRUTICULTURA. Santa Cruz do Sul: Gazeta Santa Cruz, 2006. p.61.

AZEREDO, H.M.; JARDINE, J.G. Desidratação osmótica de abacaxi aplicada à tecnologia de métodos combinados. Ciência e Tecnologia de Alimentos, v.20, p.78-82, 2000.

BOLIN, H.R.; HUXSOLL, C.C.; JACKSON, R. Effect of osmotic agents and concentration on fruit-quality. Journal of Food Science, v.48, p.202-205, 1983.

INSTITUTO ADOLFO LUTZ. Normas analíticas do Instituto Adolfo Lutz: métodos químicos e físicos para análise de alimentos. 2 ed. São Paulo: Instituto Adolfo Lutz, 1985. 317 p.

LERICI, C.R.; PINNAVAIA, G.; ROSA, M.; BARTOLUCCI, L. Osmotic dehydration of fruits. Influence of osmotic agents on drying behavior and product quality. Journal of Food Science, v.50, p.1217-1226, 1985.

MeIlgaARD, M.; CIVIlle, G.V.; CARR, B.T. Sensory evaluation techniques. Boca Raton: CRC Press, 1999. 387p.

ORDÓÑEZ, J.A. Tecnologia de alimentos: componentes dos alimentos e processos. São Paulo: Artmed, 2005. 294p.

SAS INSTITUTE. SAS system for Windows: release 8.02. Cary: SAS Institute, 2001.

SOUSA, P.H.M.; SOUZA NETO, M.A.; MAIA, G.A.; SOUZA FILHO, M.S.M.; FIGUEIREDO, R.W. Desidratação osmótica de frutos. Boletim da Sociedade Brasileira de Ciência e Tecnologia de Alimentos, v.37, p.94-100, 2003.

TEDJO, W.; TAIWO, K.; ESHTIAGHI, M.N.; KNORR, D. Comparison of pretreatment methods on water and solid difusion kinetcs of osmotically dehydrate mangos. Journal of Food Engineering, v.53, p.133-142, 2002.

TORRES, J.D.; TALENS, P.; CAROT, J.M.; CHIRALT, A.; ESCRICHE, I. Volatile profile of mango (Mangifera indica L.), as affected by osmotic dehydration. Food Chemistry, v.101, p.219-228, 2007.

TORRES, J.D.; TALENS, P.; ESCRICHE, I.; CHIRALT, A. Influence of process conditions on mechanical properties of osmotically dehydrated mango. Journal of Food Engineering, v.74, p.240246, 2006.

VIAL, C.; GUILBERT, S.; CUQ, J.L. Osmotic dehydration of kiwi fruits: influence of process variables on the color and ascorbicacid content. Sciences des Aliments, v.11, p.63-84, 1991.

$\overline{\text { Received August }}$ 17, 2007

Accepted June 27, 2008 